$$
\begin{aligned}
& S F \\
& 258 \\
& .4 A_{5} \\
& 1912
\end{aligned}
$$




$$
\text { ชิ }
$$


AN ORDINANCE

REGULATING THE

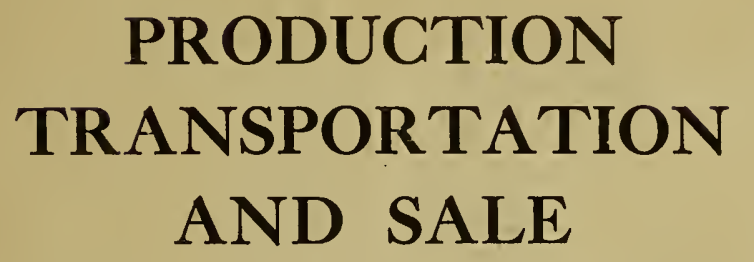

OF

Inspected and Pasteurized Milk

IN THE

CITY OF CHICAGO Ondinancer, ets.

And Repealing Sections 1273 and 1274 of the Chicago Code of 1911

\author{
G. B. YOUNG \\ Commissioner of Health
}

Passed by the City Council of the City of Chicago, August 14th, 1912 
of Health, stating the name and residence of the applicant and the location and description of the premises where such milk is to be produced, bottled or handled.

The Commissioner of Health shall thereupon make, or cause to be made, an inspection of the premises, cows and the milk produced, and the manner of handling the milk, cream, skim mill;, or buttermilk, and if the same are found to comply with the requirements as hereinafter set forth, he shall issue a permit allowing the milk, eream, skim milk or buttermilk produced or handled on said premises to be brought into or sold in the City of Chicago, conditioned that the person, firm or corporation given such permit will report at once any and all sickness occurring in himself or any or all persons residing or employed upon such premises, and will not ship into, deliver, sell or offer for sale in the City of Chicago or bring or deliver to any creamery or bottling plant supplying the City of Chicago, the milk, cream, skim milk or buttermilk produced on said premises, whenever a case of contagious or infectious disease is known or suspected of having occurred in himself or any or all other persons residing or employed upon said dairy farm, or in the families of any person or persons so employed or in any dwelling in which said person or persons shall be domiciled.

Every such permit to produce inspected milk shall expire on the 30th day of June following the date of issue, and every such permit to bottle, or handle in bulk inspected milk shall expire on the 31 st day of December following its issue.

The Commissioner of Health, when it shall appear to his satisfaction that the provisions of this article have not been complied with, may at any time revoke such a permit by giving notice in writing.

"Inspected" milk, cream, skim milk or buttermilk shall be produced and handled in accordance with the following regulations:

(a) It shall be produced on farms scoring not less than 65 on the following score card; provided, however, that after January 1st, 1915, farms on which inspected milk is produced shall score not less than 70 on this same score card. 
SCORE CARD.

EQuirMent

cows.

Condition .............

Health (outward appearance)

Comfort

Bedding $\ldots \ldots \ldots \ldots \ldots .2$

Temperature of stable....1

Protected yard ...........1

Cubic feet of space per cow:

Over 300,2 ; over 400,4 ;

Feed 500 to $1,000,6 \ldots \ldots \ldots$

Water

Clean $\cdots \cdots \cdots \cdots \cdots \cdots \cdots$

Fresh $\ldots \ldots \ldots \ldots \ldots \ldots \ldots \ldots \ldots \ldots .2$

STABLE.

Location ..................

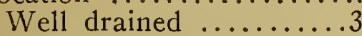

Free from contaminating surroundings $\ldots \ldots \ldots .3$

Construction...$\ldots \ldots \ldots$.

Tight, sound floor .......

Gutter ................

Stall, Stanchion tie .....

Low-down manger .....1

Smooth, tight walls .....1

Smooth, tight ceiling ....2

Box stall ............

Light: 1 sq. ft. glass per cow, $2 ; 2$ sq. ft. $4 ; 3$ sq. ft. $6 ; 4$ sq. ft. 8 ; even distribution, 2;

Ventilation: Sliding windows, 2 ; hinged at bottom, 4; King system or muslin curtain ........8

Stable yard (drainage).... MILK ROOM.

Location...$\ldots \ldots \ldots \ldots$.

Convenience $\ldots \ldots \ldots \ldots \ldots 2$

Free from contaminating surroundings $\ldots \ldots \ldots 4$

Construction

Floor $\ldots \ldots \ldots \ldots \ldots \ldots \ldots \ldots \ldots \ldots .1 .5$

Walls and ceiling .......

Light $\ldots \ldots \ldots \ldots \ldots \ldots \ldots .5$

Ventilation $\ldots \ldots \ldots \ldots \ldots \ldots .5$

Screens $\ldots \ldots \ldots \ldots \ldots \ldots \ldots .5$

Arrangement ..............

Equipment $\ldots \ldots \ldots \ldots \ldots \cdots$

Hot water or steam ....2

Cooler ................2

Narrow top milk-pail....

Other utensils ...........

Water supply for utensils..

Clean ................

Convenient $\ldots \ldots \ldots \ldots \ldots . .2$

Abundant...$\ldots \ldots \ldots \ldots \ldots .2$

Milking suits

Total
Score

erf. Al'w'd.

$4 \quad \ldots$

$\begin{array}{ll}4 & \cdots \\ 6 & \cdots \\ 4 & \cdots\end{array}$

4

$\begin{array}{ll}6 & \\ 4 & \\ 8 & \cdots\end{array}$

6

10

10

8

2

6

..

METHODS

Score

cows.

Cleanliness

Perf.Al'w'd

STABLE.

Cleanliness

Floor.$\ldots \ldots \ldots \ldots \ldots \ldots \ldots$,

Walls..$\ldots \ldots \ldots \ldots \ldots \ldots \ldots .2$

Ceiling ................2

Ledges ...............

Mangers and partitions...1

Windows ............

No other animals in sta-

ble ...................

Stable air ................

Removal of manure ........

To field or proper pit...4

30 feet from stable......2

Cleanliness of stable yard.. MILK P.OOM.

Cleanliness $\ldots \ldots \ldots \ldots \ldots$.

Care and cleanliness of utensils

Inverted in pure air.......

Clean (superficially) ....4

Sterilized ...........

MILIING.

Cleanliness $\quad . \ldots \ldots \ldots \ldots$.

Clean, dry hands ....... 4

Udders washed and dried 10

Cleaned with moist cloth 8

Cleaned with dry cloth.. 4

Cooling ..........

Removed from stable immediately after milking each cow and promptly cooled ...............10

Cooled to $50^{\circ} \mathrm{F}$. or be-

low ................10

$51^{\circ}$ to $55^{\circ} \mathrm{F} \ldots \ldots \ldots \ldots .8$

$56^{\circ}$ to $60^{\circ} \mathrm{F} \ldots \ldots \ldots \ldots .66$

Storing $\ldots \ldots \ldots \ldots \ldots \ldots \ldots \ldots$

Below $50^{\circ} \mathrm{F} . \ldots \ldots \ldots \ldots$.

$51^{\circ}$ to $55^{\circ} \mathrm{F} \ldots \ldots \ldots \ldots 66$

$56^{\circ}$ to $60^{\circ} \mathrm{F} \ldots \ldots \ldots \ldots \ldots .4$

Transportation $\ldots \ldots \ldots \ldots \ldots$

Iced in summer ......... in

Jacket or wet blanket in summer ........... 8

Dry blanket $\ldots \ldots \ldots \ldots, 4$

Covered wagon $\ldots \ldots \ldots 2$

Total $\ldots \ldots \ldots \ldots \ldots \overline{100} \ldots$

Score of equipment.... $\times 1=\ldots$

Methods $. . \ldots \ldots \ldots \ldots \times 2=\ldots$.

Total $\div 3=\ldots \ldots$ Final Score.

(b) It shall be obtained from cows which have been certified, by veterinarians authorized by the Commissioner of Health, or by veterinarians 
appointed by the state or United States government, to be free from tuberculosis and other diseases, not more than six months prior to the date that such milk is brought into the city, provided, however, that time shall be given until June 30, 1913, for the filing of such certificates.

Animals known to be affected with tuberculusis or other infectious diseases shall not be kept in herds used for the production of inspected milk.

The cows yielding same must be kept clean. Long hair must be clipped from the flanks, udder and from the tail sufficiently to clear the ground. The cows shall not be fed on slops, refuse of any distillery or brewery, glucose or any malt in a state of fermentation, putrefaction or decomposition, or any other putrefying or unwholesome foodstuffs. Milk from cows fifteen days before and one week after calving shall not be mixed with inspected milk.

(c) The milking must be done by milkers who are clean as to both clothing and person or by mechanical milkers operated by persons as above specified. When open milk pails are used they sha11 have an opening at the top not more than seven inches in diameter.

(d) All utensils, mechanical milkers or other devices, used in the production and handling of inspected milk must be properly cleaned and sterilized each time before using, and shall be so constructed that all parts arc absolutely free from places where milk can accumulate or soak in so that it cannot be removed by simple washing, and the surface coming in contact with the milk or cream must be smooth and free from excessive rust.

(e) All persons living upon farms where such milk is produced, or employed thereon, shall be free from contagious or infectious diseases, and resident or domiciled in places free from such diseases, and shall not be exposed to or come in contact with any person suffering with or having a contagious disease, provided that no person shall be employed or permitted to work on such farm unless and until it shall have beerl demonstrated to the satisfaction of the Commissioner of Health of the City of Chicago that said person is not a typhoid or diphtheria carrier.

It shall be the duty of every per- son, firm or corporation producing inspected milk to notify the Commissioner of Health at once, by mail, of the occurrence of any sickness in any person, or persons, living or employed on their farms where such milk is produced. Milk, cream, skim milk or buttermilk produced on any farm or bottled or handled in bulk where a case of contagious or infectious disease has occurred, or is suspected to have occurred, shall not be shipped into or delivered, sold or offered for sale in the City of Chicago, or brought or delivered to any creamery or bottling plant supplying the City of Chicago until the Commissioner of Health shall have been notified and shall have made an investigation and released such milk, cream, skim milk or buttermilk for delivery in the City of Chicago.

(f) The milk from each cow shall be removed from the stable immediately after it is obtained, and shall then be strained and cooled at once to 60 degrees Fahrenheit or below. It shall then be kept at a temperature of 60 degrees Fahrenheit or below until delivered to the consumer, provided that after June 1, 1914, the temperature to which the milk must be cooled and at or below which it must be kept shall be 55 degrees Fahrenheit.

(g) Inspected milk, cream, skin milk or buttermilk exposed for sale, offered for sale or sold to the consumer, shall be contained in tightly closed and capped bottles, or receptacles of a similar character.

(h) All milk, cream, skim milk, or buttermilk produced and handled in the manner required in Article A of this section shall be labeled "Inspected Milk," "Inspected Cream," "Inspected Skim Milk," or "Inspected "Buttermilk," as the case may be, in letters not less than ${ }_{16}^{3}$ of an inch high on the cap or cover of every package when contained in bottles or receptacles of a similar character, and not less than $5 / 8$ of an inch high, on $a$ tag, attached to each container, when contained in cans. The serial number corresponding with the number of the permit given by the Commissioner of Health to the person, firm or corporation producing such inspected milk, cream, skim milk or buttermilk shall be plainly indicated in figures not less than $5 / 8$ of an inch high on every case, can or receptacle of a similar char- 
acter in which such milk, cream, skim milk or buttermilk is sent or brought into the City of Chicago.

The cap or stopper of the bottles or receptacles of a similar character in which said inspec'ed milk, cream, skim milk or-buttermilk shall be contained shall be plainly marked with the name of the day of the week upon which the said milk, cream, skim milk or buttermilk was first enclosed in bottles or receptacles of a similar character, provided, that it shall be unlawful for any person, firm or corporation to mark, cause to be marked, or permit to be marked upon any bottle or receptacle of similar character containing inspected milk, creann, skim milk, or buttermilk the name of any other day than that upon which the contents was first enclosed in bottles or containers of similar character.

(i) All inspected milk, cream, slkin milk or buttermilk sold, offered for sale or kept with the intention of selling or brought into the City of Chicago shall not yield more than a perceptible amount of sediment or stain other than that of natural butterfat, when a pint sample of the same is filtered through a pledget of cotton one inch in diameter, and shall be entirely free from disease producing bacteria and blood, pus or other matter or things dangerous and detrimental to health.

Inspected milk and inspected skim milk shall not contain more than 100 000 bacteria per c. c. from October 1 to May 1, inclusive, and not more than 150,000 bacteria from May 2 to September 30, inclusive. Inspected cream shall not contain more than 150,000 bacteria per c. c. from October 1 to $\mathrm{May} 1$, inclusive, and not more than 300,000 bacteria from May 2 to September 30, inclusive.

In the determination of the number of bacteria the culture media used shall be 1 per cent agar agar, having a reaction of plus 1.5 on Fullers' scale.

The quantity of culture media used shall be 10 cubic centimeters per plate. The Petri dishes shall be 100 millimeters in diameter.

The Plate cultures shall be incubated at a temperature of $37^{\circ}$ Centigrade, for a period of two days.

The Petri dishes selected for counting shall be those containing not less than 20 nor more than 200 colonies per plate.

B. Pasteurized Milk.) All milk, cream, skim milk or buttermilk not complying with the requirements set forth for inspected milk in Article A of this section shall be produced, handled and pasteurized in accordance with the following regulations.

(a) The said milk, cream, skim milk or buttermilk shall be produced on farms scoring not less than 55 on the score card as described in paragraph (a) in Article A of this section.

(b) It shall be obtained from cows which, upon physical examination, are found to be free from disease. The cows shall be kept clean and shall not be fed on slops, refuse of any distillery or brewery, glucose or any malt in a state of fermentation, pirtrefaction or decomposition, or any other putrefying or unwholesome foodstuffs. Milk from cows fifteen days before and one week after calving shall not be mixed with pastenrized milk.

(c) The milking must be done in a cleanly manner. When open milk pails are used they shall have an opening at the top not more than seven inches in diameter.

(d) All utensils used in the production and handling of pasteurized milk must be properly cleaned and sterilized each time before using, and shall be so constructed that all parts are absolutely free from places where milk can accumulate or soak in so that it cannot be removed by simple washing, and the surface coming in contact with the milk or cream must be smooth and free from excessive rust.

(e) All persons living upon farms where such milk is produced, or employed thereon, shall be free from contagious or infectious diseases, and resident or domiciled in places free from such diseases, provided that no person shall be employed or permitted to work who is known to be a "carrier" of an infectious or contagious disease.

(f) The milk from each cow shall be removed from the stable immediately after it is obtained, and shall then be strained and cooled at once to 60 degrees Fahrenheit or below 
and kept at this temperature until pasteurized, provided that after June 1, 1914, the temperature to which the milk must be cooled, and at or below which it must be kept shall be 55 degrees Fahrenheit.

(g) All milk, cream, skim milk or buttermilk required to be pasteurized shall not yield more than a perceptible amount of sediment or stain other than that of natural butterfat when a pint sample of the same is filtered through a pledget of cotton one inch in diameter, and shall be entirely free from disease producing bacteria, and blood, pus, or other matter or things dangerous and detrimental to health.

Such milk and skim milk, before pasteurization, shall not contain more than 750,000 bacteria per c. c. from October 1 to May 1, inclusive, and not more than $1,000,000$ bacteria per c. c. from May 2 to September 30 , inclusive.

Such cream shall not contain more than 800,000 bacteria per c. c. from October 1 to May 1 , inclusive, and not more than $1,500,000$ bacteria from May 2 to September 30, inclusive.

(h) Every person, firm or corporation installing or operating a pasteurizer for the purpose of pasteurizing or treating milk, cream, skim milk or buttermilk to be sold, offered for sale or kept with the intention of selling, or for the pasteurization or treatment of milk, cream, skim milk or buttermilk to be shipped or brought into the City of Chicago, shall notify the Commissioner of Health in writing, stating the time when and the place where such pasteurizer is to be installed, together with the name of the person or persons who will operate said pasteurizer, and shall file with said. Commissioner of Health the names of the owners and the location of all farms from which the milk that is to be pasteurized at said plant is obtained.

The Commissioner of Health shall thereupon make or cause to be made ain inspection of such pasteurizer and the premises or plant wherein the same is operated. He shall also inspect or canse to be inspected all farms the milk supply of zolich, after pasteurization at said plant, is sold or intended for sale or brought into the
City of Chicago with the intention of selling for humian consumption; and no such farms shall be allowed to bring or furnish milk, or cream to said pasteurizing plant without first being inspected and found to comply with the requirements of $\mathrm{Ar}$ ticle $B$ of this ordinance.

It shall be unlawful for any person, firm or corporation operating such a pasteurizer or pasteurizing plant to receive milk or cream from any farm which has not been inspected and passed by the Commissioner. of Health.

If all of the foregoing provisions have been complied with, and the pasteurizer or pasteurizing equipment is such that 99 per cent of all bacteria and all pathogenic bacteria are killed in the milk treated therein at the temperature required in paragraphs $(j)$ and $(l)$ of Article $B$ of this ordinance, the Commissioner of Health shall issue a permit allowing the milk, cream, skim milk or buttermilk pasteurized in such pasteurizer and on such premises to be brought into or sold in the City of Chicago. Every such permit shall expire on the $30 t h$ day of June following date of issue.

The Commissioner of Health may withdraze his approval by serving notice in writing when any such pasteurizer or pasteurizing plant is not operated in accordance zuith the provisions of this ordinance or when the mille received thereat or pasteurised therein is obtained from farms that do not comply with the requirements as set forth in Article $B$ of this ordinance or from farms which have not been inspected and found to comply with said requirements by the Commissionor of Health.

In case of dispute in regard to tests made of such pasteurizer or pasteurising equipment or in regard to the temperature to which the milk shall be heated, the person, firm or corporation making application to operate a pasteurizer may make application to the Conmissioner of Health to have the said pasteurizer or pasteurizing equipment re-inspected. Such re-inspection or retesting shall be done by one person designated by the Conmissioner of Health and another by the person, firm or corporation owning or operating said pastcurizer, and in case of failure or inability to agree, the two to select a third. 
(i) In all continuons pasteurization the milk and cream shall be heated to a temperature which shall be determined and fixed by the Commissioner of Health for cach machine at a point corresponding to a tcmperature required to kill 99 per cent of the bacteria and all pathogenic bacteria contained in the raw product, and shall show no colon bacilli in 1 c. c. as determined by cultural methods.

A11 continuous pasteurizers shall be equipped with feeding pipe which is so constructed that the pasteurizer cannot be fed in excess of its normal working capacity, that is, in excess of the working capacity of the machine at which 99 per cent of the bacteria are killed when the required amount of heat is applied.

A recording apparatus shall be in stalled upon all pasteurizers to record during operation the temperature of the pasteurized product as it flows from the heater. The thermometer of this recording apparatus must be accurate and kept submerged in the milk in such a way that it is not exposed to escaping steam or other heat, except the heated milk, provided that if the pasteurizing is done in bottles or in other final containers, the temperature recording apparatus must be attached and adjusted in a manner so as to accurately recoró the temperature to which the milk, cream, skim milk or buttermilk is raised and the duration of time for which said temperature is maintained.

The records made by this recording thermometer must be accurate and made in a chamber which is kept under lock and key in the control of the Commissioner of Health.

The mechanism of the pasteurizer or pasteurizing system shall be such that the three important elements, namely, the temperature, time of exposure and the quantity of milk exposed at one time can be readily kept under control and observation by the Commissioner of Health.

(j) The following conditions as to degrees of heat and time of exposure shall be complied with:

A uniform heating of 140 degrees Fahrenheit for 20 minutes, or 150 degrees Fahrenheit maintained for 15 minutes, or 155 degrees Fahrenheit maintained for 5 minutes, or 160 dcgrees Fahrenheit maintained for $1 \frac{1}{2}$ minutes, or 165 degrees lahrenheit maintained for 1 minute. The time shall be calculated from the period that the entire quantity reaches the required temperature.

(k) All milk, cream, skim milk or buttermilk produced and handled in the manner required in Article $B$ of this section shall be labeled "Pasteurized Milk," "Pasteurized Cream," "Pasteurized Skim Milk," or "Pastelirized Buttermilk," as the case may be, in letters not less than $\frac{3}{16}$. of an inch high on the cap or cover of every package, when contained in bottles or receptacles of a similar character, and not less than $5 / 8$ of an incl high, on a tag attached to each container, when contained in cans, together with a serial number corresponding witi the number of the permit given by the Commissioner of Health, to the person, firm or corporation for the pasteurizer or plant, pasteurizing said milk, cream, skim milk or buttermilk, and the cap or stopper of the bottles or receptacles of a similar character in which said pasteurized milk, cream, skim milk or buttermilk shall be contained shall be plainly marked with the name of the day of the week upon which said milk, cream, skim inilk or buttermilk enclosed in said bottles or receptacles of a similar character, was pasteurized, provided, that it shall be unlawful for any person, firm or corporation to mark, cause to be marked, or permit to be marked upon any bottle or receptacle of similar character containing pasteurized milk, cream, skim milk or buttermilk the name of any other day than that upon which the contents enclosed in bottles or containers of similar character was pasteurized.

(1) After January 1; 1914,. all milk, cream, skim milk or buttermilk which is not of the grade $0:$ kind defined in this section as "Iispected" shall be pasteurized at a temperature of not less than 140 degrees Fahrenheit for not less than 20 minutes or not less than 155 de grees Fahrenheit for not less than 5 minutes.

(m) The pasteurized product shall be cooled at once to a temperature of 45 degrees Fahrenheit or below. This cooling shall be so conducted that the pasteurized product is not exposed to possible sources of contamination. 
This cooling apparatus shall be so constructed that it can be readily cleaned and sterilized.

Milk, cream or skim milk shall be enclosed in tightly capped bottles or packages of a similar character or in sealed cans immediately after pastouriation.

Pasteurized milk, cream, skim milk or buttermilk shall be kept at a temperature of 50 degrees Fahrenheit or below while the same is stored or lept at a pasteurizing plant, bottling establishment or milk depot.

Pasteurized milk, cream, skim milk or buttermilk exposed for sale, offered for sale or sold to the consumer, shall be contained in tightly closed and capped bottles, or receptacles of a similar character.

Pastenrized milk and skim milk shall not contain more than 50,000 bacteria per c. c. from October 1 to May 1, inclusive, and not more than 100,000 bacteria per c. c. from Miay 2 to September 30 , inclusive. Pasteut. ized cream shall not contain more than 150,000 bacteria per c. c. from October 1 to May 1 , inclusive, and not more than 300,000 bacteria per c. c. from May 2 to September 30, inclusive, and shall not contain colon bacilli in 1 c. c. as determined by cultural methods.

In the determination of the number of bacteria, the culture media used shall be 1 per cent agar agar, having a reaction of plus 1.5 on the Fuller scale.

The quantity of culture media used shall be 10 cubic centimeters per plate. The Petri dishes shall be 10 ? millimeters in diameter.

The plate cultures shall be incuhated at a temperature of $37^{\circ}$ Centigrade, for a period of two days.

The Petri dishes selected for counting shall be those containing not less than 20 nor more than 200 colonies per plate.

(n) Milk, cream, skim milk or buttermilk which has been pasteurized and held for a period of twelve hours or more after such pasteurization shall not be repasteurized or reheated for the purpose of enhancing the keeping qualities of such milk, cream, skim milk or buttermilk.

1274. Penalty and Seizure.) Every person, firm or corporation violating any of the provisions of the foregoing section shall be fined not less than $\$ 5.00$ or more than $\$ 200.00$ for each and every offense, provided, however, that whenever the Commissioner of Health of the City of Chicago shall discover that any person, firm or corporation has violated any of the provisions of the foregoing sections, said Commissioner shall within ten days from the date of such discoiery, before suit is commenced, notify in writing the person, firm or corporation guilty of said violation that said riolation has occurred, said notice to state the particular provision of the foregoing section or sections that has been violated. All milk. cream, skim milk or buttermilk brought into the City of Chicago, or sold, offered for sale, or kept with the intention of selling, or of using in the manufacture of ice cream which does not comply with the requirements as set forth in the foregoing section, or with the standards therein set forth, shall be condemned by the Commissioner of Health and rendered unfit for human food loy coloring or otherwise treating, or shall be condemned, seized and destroyed, provided, that if in the opinion of the Commissioner of Health it is proper to do so the said milk, cream, skim milk or buttermilk may be tagged as follows: "Condemned, Commissioner of Health, Chicago," and returned to the shipper or producer.

Section 2. This ordinance shall take effect from and after its passage. 


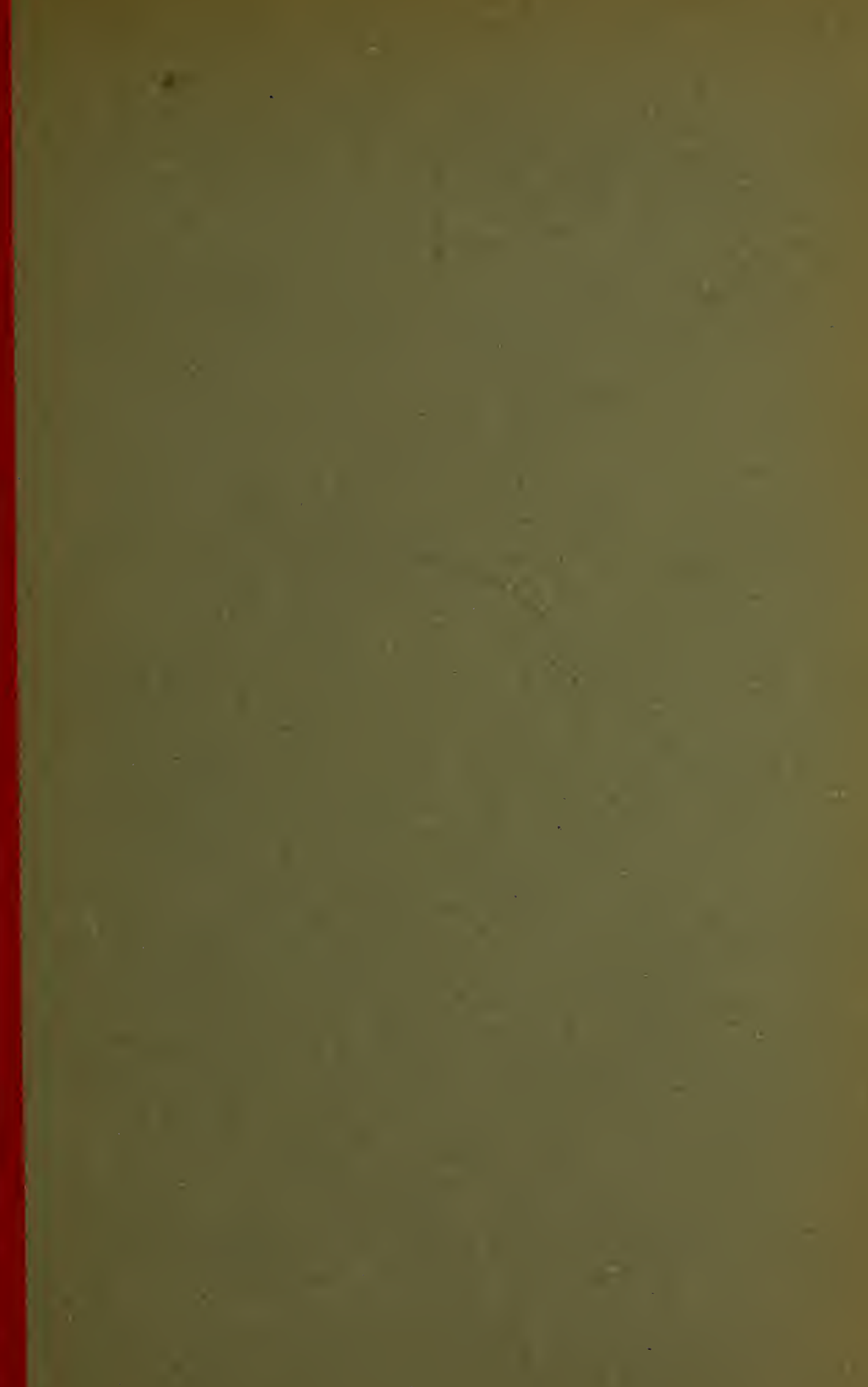




\section{LIBRARY OF CONGRESS}

|||||||||||||||||||||||||||||||||||||||||||

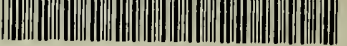

00008960355 